\title{
Lymphocyte respiration in children with Trisomy 21
}

Elhadi H Aburawi* and Abdul-Kader Souid

\begin{abstract}
Background: This study measured lymphocyte mitochondrial $\mathrm{O}_{2}$ consumption (cellular respiration) in children with trisomy 21.

Methods: Peripheral blood mononuclear cells were isolated from whole blood of trisomy 21 and control children and these cells were immediately used to measure cellular respiration rate. $\left[\mathrm{O}_{2}\right]$ was determined as a function of

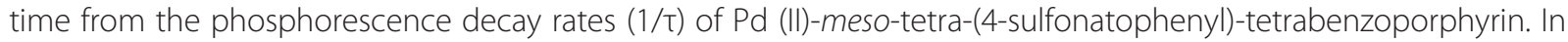
sealed vials containing lymphocytes and glucose as a respiratory substrate, $\left[\mathrm{O}_{2}\right]$ declined linearly with time, confirming the zero-order kinetics of $\mathrm{O}_{2}$ conversion to $\mathrm{H}_{2} \mathrm{O}$ by cytochrome oxidase. The rate of respiration ( $k$, in $\mu \mathrm{M}$ $\mathrm{O}_{2} \min ^{-1}$ ), thus, was the negative of the slope of $\left[\mathrm{O}_{2}\right]$ vs. time. Cyanide inhibited $\mathrm{O}_{2}$ consumption, confirming that oxidation occurred in the mitochondrial respiratory chain.
\end{abstract}

Results: For control children (age $=8.8 \pm 5.6$ years, $\mathrm{n}=26$ ), the mean $\left( \pm \mathrm{SD}\right.$ ) value of $k_{c}$ (in $\mu \mathrm{M} \mathrm{O}_{2}$ per min per $10^{7}$ cells) was $1.36 \pm 0.79$ (coefficient of variation, $C V=58 \%$; median $=1.17$; range $=0.60$ to $3.12 ;-2 \mathrm{SD}=0.61$ ). For children with trisomy 21 (age $=7.2 \pm 4.6$ years, $n=26)$, the values of $k_{c}$ were $0.82 \pm 0.62(C v=76 \%$; median $=0.60$; range $=0.20$ to 2.80), $p<0.001$. Similar results $(p<0.000)$ were obtained after excluding the five trisomy 21 children with elevated serum TSH (values $>6.1 \mathrm{mU} / \mathrm{L}$ ). Fourteen of $26(54 \%)$ children with trisomy 21 had $k_{c}$ values of 0.20 to 0.60 (i.e., $<-2 S D$ ). The values of $k_{c}$ positively correlated with body-mass index (BMI, $\left.R>0.302\right)$, serum creatinine $(R>0.507)$, blood urea nitrogen (BUN, $R>0.535)$ and albumin $(R>0.446)$.

Conclusions: Children with trisomy 21 in this study have reduced lymphocyte bioenergetics. The clinical importance of this finding requires further studies.

Keywords: Oxygen, Respiration, Mitochondria, Trisomy 21, Hypothyroidism

\section{Background}

Trisomy 21 is the most common chromosomal anomaly worldwide, affecting about 1 in 700 newborns [1]. These individuals typically have low resting metabolic rates [2] and are particularly susceptible to infections [3] and hypothyroidism [4]. Moreover, defects in the inner mitochondrial membrane potential [5] and mitochondrial respiratory chain enzymes are documented in these patients [6,7]. Mitochondrial disturbances, increased oxidative stress and apoptosis have been described in the neurons, predisposing to precocious Alzheimer's disease [8]. Alterations in metabolic enzymes (e.g., monoamine oxidase- $\mathrm{B}$, cytochrome oxidase, isocitrate dehydrogenase

\footnotetext{
* Correspondence: e.aburawi@uaeu.ac.ae

Department of Pediatrics, UAE University, P.O. Box 17666, Al Ain, United Arab Emirates
}

and glutamate dehydrogenase) have been also linked to impaired energy metabolism in trisomy 21 children [9]. Calcium levels are lower than in control children, which may alter cellular signaling [10].

Increased congenital heart disease and other major anomalies are exceptionally frequent in children with trisomy 21. It is not known whether these defects are linked to the biological impairments described above.

The use of the phosphorescence oxygen analyzer to measure lymphocyte respiration was recently reported. Lymphocytes were shown to be suitable for screening of certain mitochondrial disorders [11]. These methodologies were used to measure lymphocyte respiration rates in children with trisomy 21 and compare them with rates in children without this disorder. 


\section{Methods}

\section{Reagents and solutions}

Pd (II) complex of meso-tetra-(4-sulfonatophenyl)-tetrabenzoporphyrin was purchased from Porphyrin Products (Logan, UT). Glucose oxidase (powder from Aspergillus niger), D (+) glucose anhydrous, Histopaque-1077 and remaining reagents were purchased from Sigma-Aldrich (St. Louis, MO).

Pd phosphor solution $(2.5 \mathrm{mg} / \mathrm{ml}=2 \mathrm{mM})$ was prepared in distilled water $\left(\mathrm{dH}_{2} \mathrm{O}\right)$ and stored at $-20^{\circ} \mathrm{C}$. Glucose oxidase solution was prepared in $\mathrm{dH}_{2} \mathrm{O}(10 \mathrm{mg} /$ $\mathrm{mL})$ and stored at $-20^{\circ} \mathrm{C}$. Sodium cyanide $(\mathrm{NaCN})$ solution $(1.0 \mathrm{M})$ was prepared in $\mathrm{dH}_{2} \mathrm{O}$; the $p \mathrm{H}$ was adjusted to $\sim 7.0$ with $12 \mathrm{~N} \mathrm{HCl}$ and stored at $-20^{\circ} \mathrm{C}$. Phosphatebuffered saline (PBS) containing glucose $(137 \mathrm{mM} \mathrm{NaCl}$,

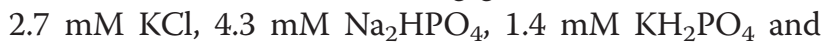
$10 \mathrm{mM}$ glucose; $p \mathrm{H}$ 7.4) was stored at $4^{\circ} \mathrm{C}$.

\section{Subjects}

Venous blood samples (5 to $8 \mathrm{~mL}$ ) were collected in heparin tubes and processed in $<2 \mathrm{hr}$ for peripheral blood mononuclear cell (PBMC) isolation and $\mathrm{O}_{2}$ measurement. Blood was also collected from age- and gender-matched healthy controls. All trisomy 21 participants attended the outpatient facilities at Tawam and $\mathrm{Al}$ Ain Hospitals (Al Ain city, Abu Dhabi) for routine visits. All control participants were healthy children who had no medical complaints.

The study was approved by the institutional review board for protection of human subjects. Informed consent was obtained for each participating subject.

\section{PBMC isolation}

Plasma was collected from blood samples by centrifugation and possessed for Comprehensive Metabolic Panel and lipid profile. The samples were then diluted with equal volume of phosphate-buffered saline (PBS) containing $10 \mathrm{mM}$ glucose and gently layered on the top of $10 \mathrm{~mL}$ Histopaque-1077. The mixtures were centrifuged at $15^{\circ} \mathrm{C}, 400 \mathrm{xg}$ for $30 \mathrm{~min}$. Collected PBMC were diluted with the same solution and re-centrifuged as above. The pellets were suspended in PBS, $10 \mathrm{mM}$ glucose, $3 \mu \mathrm{M}$ Pd phosphor and $0.5 \%$ fat-free bovine serum albumin for $\mathrm{O}_{2}$ measurements at $37^{\circ} \mathrm{C}$. Cell count and viability were determined by light microscopy, using a hemocytometer under standard trypan blue staining conditions. Only trypan blue-negative cells (>95\%) were counted.

\section{Oxygen instrument}

A phosphorescence oxygen analyzer that measures dissolved $\mathrm{O}_{2}$ in solutions as function of time was used to determine the rate of $\mathrm{PBMC}$ respiration $[12,13]$. This method is based on the principle that $\mathrm{O}_{2}$ quenches the phosphorescence of a palladium phosphor [14].

The Pd (II) derivative of meso-tetra-(4-sulfonatophenyl)-tetrabenzoporphyrin had an absorption maximum at $625 \mathrm{~nm}$ and a phosphorescence emission maximum at $800 \mathrm{~nm}$. Samples were exposed to light flashes (10 per sec) from a pulsed light-emitting diode array with a peak output at $625 \mathrm{~nm}$. Emitted phosphorescent light was detected by a Hamamatsu photomultiplier tube after first passing it through a wide-band interference filter

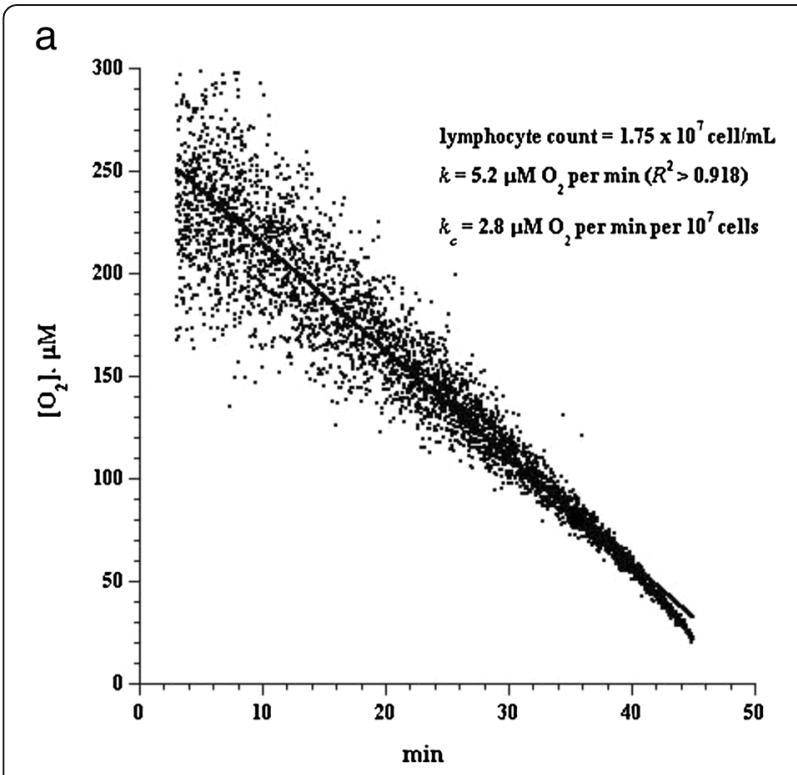

b

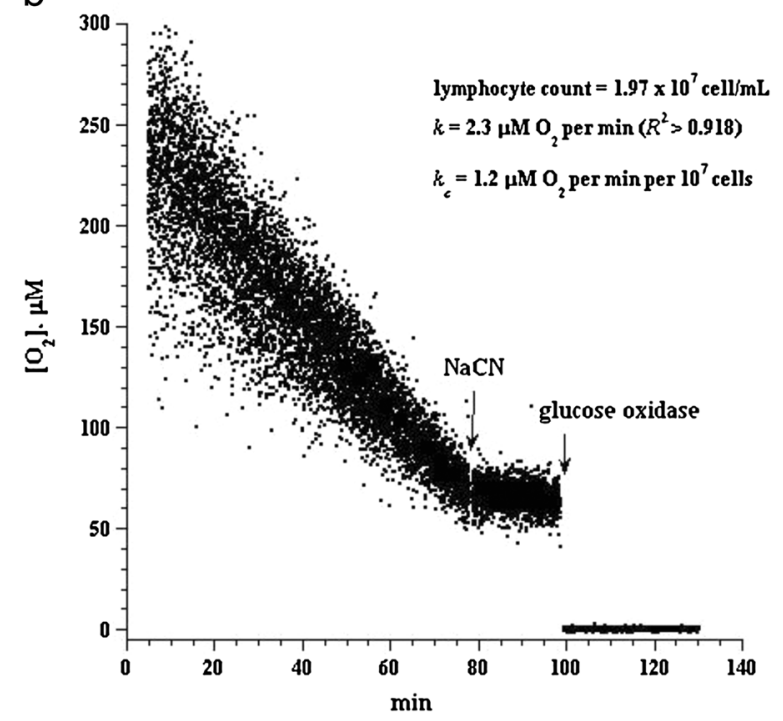

Figure 1 Representative $\mathrm{O}_{2}$ runs for lymphocyte respiration in a 15-year-old male with trisomy 21 (Panel a, Subject 8 in Table 1) and control subject (Panel b). The lines are best linear fits $\left(R^{2}>0.830\right)$. The additions of $10 \mathrm{mM} \mathrm{NaCN}$ and $50 \mu \mathrm{g} / \mathrm{mL}$ glucose oxidase are shown. 
centered at $800 \mathrm{~nm}$. Amplified phosphorescence was digitized at 1-2 $\mathrm{MHz}$ using an analog/digital converter (PCI-DAS 4020/12 I/O Board) with 1 to $20 \mathrm{MHz}$ outputs.

The phosphorescence decay rate $(1 / \tau)$ was characterized by a single exponential; $\mathrm{I}=\mathrm{Ae}^{-t / \mathrm{\tau}}$, where $\mathrm{I}=\mathrm{Pd}$ phosphor phosphorescence intensity. The values of $1 / \tau$ were linear with dissolved $\mathrm{O}_{2}: 1 / \tau=1 / \tau^{\mathrm{o}}+k_{q}\left[\mathrm{O}_{2}\right]$, where $1 / \tau=$ the phosphorescence decay rate in the presence of $\mathrm{O}_{2}, 1 / \tau^{\mathrm{o}}=$ the phosphorescence decay rate in the absence of $\mathrm{O}_{2}$, and $k_{\mathrm{q}}=$ the second-order $\mathrm{O}_{2}$ quenching rate constant in $\sec ^{-1} \mu \mathrm{M}^{-1}$ (14). For calibration, the reaction contained PBS, $3 \mu \mathrm{M}$ Pd phosphor,
$0.5 \%$ fat-free albumin, $50 \mu \mathrm{g} / \mathrm{mL}$ glucose oxidase and various concentrations of $\beta$-glucose [11].

Cellular respiration was measured at $37^{\circ} \mathrm{C}$ in $1.0-\mathrm{mL}$ sealed vials. Mixing was carried out with the aid of parylene-coated stirring bars. The respiratory substrates were endogenous metabolic fuels supplemented with glucose.

\section{Statistical analysis}

The data are summarized by arithmetic mean and standard deviation. Mann-Whitney $U$ test was used for nonparametric values. $P<0.05$ was considered significant.

Table 1 Rates of lymphocyte respiration, thyroid function and clinical findings in trisomy 21 children

\begin{tabular}{|c|c|c|c|c|c|c|c|}
\hline Children No. & Age (yr) & Gender & $\begin{array}{l}\mathrm{BMI} \\
\left(\mathrm{kg} / \mathrm{m}^{2}\right)\end{array}$ & $\begin{array}{l}k_{c}\left(\mu \mathrm{M} \mathrm{O}_{2} \min ^{-1}\right. \\
\left.\text { per } 10^{7} \text { cells }\right)\end{array}$ & $\begin{array}{l}\text { TSH } \\
\text { (mlU/L) }\end{array}$ & $\begin{array}{l}\text { Free T4 } \\
(\mathrm{pmol} / \mathrm{L})\end{array}$ & Clinical status \\
\hline 1 & 1.5 & $\mathrm{~F}$ & 12.8 & 1.6 & 3.5 & 20.7 & AVSD \\
\hline 2 & 5 & M & 16.1 & 2.0 & 1.6 & 14.7 & celiac disease \\
\hline 3 & 17 & M & 28.6 & 1.2 & 4.9 & 9.5 & normal \\
\hline 4 & 12 & M & 16.3 & 0.6 & 2.6 & 10 & AVSD \\
\hline 5 & 12 & $\mathrm{~F}$ & 30.8 & 1.2 & 3.8 & 13.2 & VSD \\
\hline 6 & 9 & M & 17.1 & 0.6 & 2.6 & NA & bronchial asthma \\
\hline $7^{*}$ & 15 & M & 30.2 & 0.6 & 2.8 & 10.0 & aortic stenosis, hypothyroidism \\
\hline 8 & 15 & M & 44.3 & 2.8 & 13.2 & 11.0 & Moya Moya disease, hypothyroidism \\
\hline 9 & 3 & $\mathrm{~F}$ & 13.8 & 0.4 & 3.7 & 14.2 & bronchial asthma \\
\hline 10 & 2 & F & 15.2 & 0.6 & 5.3 & 13.0 & obstructive sleep apnea, low vitamin D \\
\hline 11 & 3 & M & 14.5 & 0.5 & 2.9 & 15.8 & ASD, PDA \\
\hline 12 & 5 & M & 17.5 & 0.9 & 2.6 & 9.9 & VSD \\
\hline $13^{*}$ & 4 & M & 15.7 & 0.2 & 12.6 & 11.6 & hypothyroidism \\
\hline 14 & 10 & $\mathrm{~F}$ & NA & 0.8 & 5.1 & 10.4 & normal \\
\hline 15 & 6 & M & 18.7 & 0.4 & 5.1 & 10.5 & normal \\
\hline 16 & 4 & M & 14.8 & 1.2 & 3.6 & 11.9 & normal \\
\hline 17 & 9 & F & 16 & 0.7 & 3.9 & 10.7 & normal \\
\hline 18 & 1.5 & M & 16.3 & 1.5 & 11.6 & 11.9 & hypothyroidism \\
\hline 19 & 5 & M & NA & 1.0 & 2.9 & 11.1 & normal \\
\hline 20 & 6 & M & 20.7 & 0.3 & 3.9 & 10.4 & normal \\
\hline 21 & 8 & M & 31.4 & 0.4 & 5.1 & 10.5 & asthma, myelomeningocele \\
\hline 22 & 2 & $\mathrm{~F}$ & 14.3 & 0.3 & 7.7 & 11.2 & normal \\
\hline 23 & 7 & $\mathrm{~F}$ & 17.8 & 0.3 & 1.3 & 9.3 & normal \\
\hline 24 & 8 & F & 23.2 & 0.2 & 3.7 & 11.3 & AVSD \\
\hline 25 & 6 & M & 35.1 & 0.2 & 3.6 & 14.1 & AVSD \\
\hline 26 & 4 & M & 13.6 & 0.7 & 6.4 & 14.1 & normal \\
\hline mean $\pm S D(C V)$ & $6.9 \pm 4.4$ & & $20.6 \pm 8.3(40 \%)$ & $0.82 \pm 0.62(76 \%)$ & $4.8 \pm 3.1$ & $12.0 \pm 2.5$ & \\
\hline
\end{tabular}

AVSD, atrioventricular septal defect; VSD, ventricular septal defect; ASD, atrial septal defect; PDA, patent ductus arteriosus; CV, coefficient of variation. NA, not available.

In normal 2 to7 year-old children, the TSH values are 0.10 to $5.9 \mathrm{mU} / \mathrm{L}$ (mean $=2.2 \mathrm{mU} / \mathrm{L}$ ); in normal 9 to 16 year-old children, the TSH values are 0.20 to $6.1 \mathrm{mU} / \mathrm{L}$ (mean $=2.3 \mathrm{mU} / \mathrm{L}$ )

Reference ranges for free T4 are 11.0 to $22.6 \mathrm{pmol} / \mathrm{L}$ in children 1 to 5 years of age, 11.6 to $21.5 \mathrm{pmol} / \mathrm{L}$ in children 6 to 10 years of age, and 12.0 to $20.6 \mathrm{pmol} / \mathrm{L}$ in children 11 to 19 years of age (https://www.labcorp.com/wps/portal/provider).

* On thyroxin prior to $\mathrm{O}_{2}$ consumption testing. 


\section{Results}

In cell suspensions sealed from air, $\left[\mathrm{O}_{2}\right]$ decreased linearly with time, indicating the kinetics of mitochondrial $\mathrm{O}_{2}$ consumption was zero-order. The rate of respiration ( $k$, in $\mu \mathrm{M} \mathrm{O} \mathrm{O}_{2} / \mathrm{min}$ ) was thus the negative of the slope $\mathrm{d}\left[\mathrm{O}_{2}\right] / \mathrm{d} t$. Cyanide markedly inhibited respiration $\left(\geq 96 \%\right.$ ), confirming $\mathrm{O}_{2}$ was consumed mainly by the mitochondrial respiratory chain.

Lymphocyte respiration was measured in 26 children with trisomy 21 and 26 control children. Representative $\mathrm{O}_{2}$ runs are shown in Figure 1a-b. For trisomy 21 children, the rate of respiration $\left(k_{c}\right.$, in $\mu \mathrm{M} \mathrm{O}_{2}$ per min per $10^{7}$ cells, mean $\left.\pm \mathrm{SD}, \mathrm{n}=26\right)$ was $0.82 \pm 0.62$ (median $=$ 0.60 ; range $=0.20$ to 2.80 ), Table 1 . The values of $k_{c}$ for control children $(\mathrm{n}=26)$ were $1.36 \pm 0.79$ (median $=$ 1.17 ; range $=0.60$ to $3.12 ;-2 \mathrm{SD}=0.61$ ). The $p$ value for $k_{c}$ between trisomy 21 and control children was $<0.001$, Figure 2. Similar results with higher significance $(p<0.000)$ were obtained after excluding the five children with trisomy 21 and elevated serum TSH (values $>6.1 \mathrm{mU} / \mathrm{L})$. Fourteen of 26 (54\%) children with trisomy 21 had $k_{c}$ values of 0.20 to $0.60(<-2 \mathrm{SD})$.

In children with trisomy 21 and normal TSH $(\mathrm{n}=21)$, the $k_{c}$ value did not correlate with the TSH level $\left(R^{2}>0.072\right.$, Figure 3a). By contrast, in children with trisomy 21 and abnormal lymphocyte respiration $\left(k_{c}<\right.$ $0.61, \mathrm{n}=14)$, the $k_{c}$ value correlated with the TSH level $\left(R^{2}>0.225, R>0.474\right.$, Figure $\left.3 \mathrm{~b}\right)$.

Five children with trisomy 21 had elevated TSH levels $(>6.1 \mathrm{mIU} / \mathrm{L})$. Their median TSH was $12.6 \mathrm{mIU} / \mathrm{L}$ (range, 6.4 to 13.2) and median $k_{c}$ was $0.7 \mu \mathrm{M} \mathrm{O}_{2}$ per

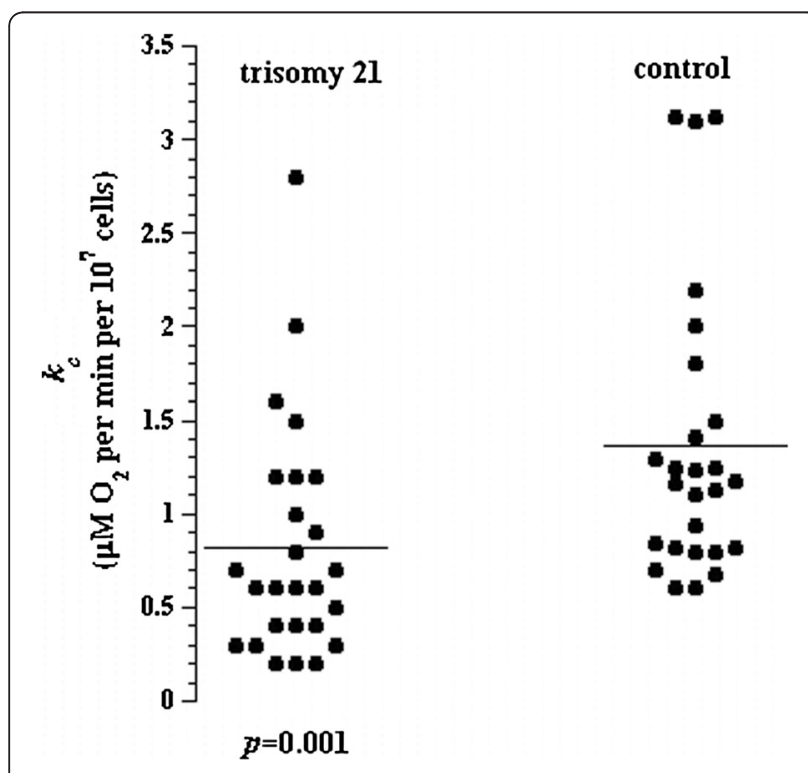

Figure $\mathbf{2}$ Lymphocyte respiration in $\mathbf{2 6}$ children with trisomy 21 and $\mathbf{2 6}$ control children. The horizontal lines are mean values.

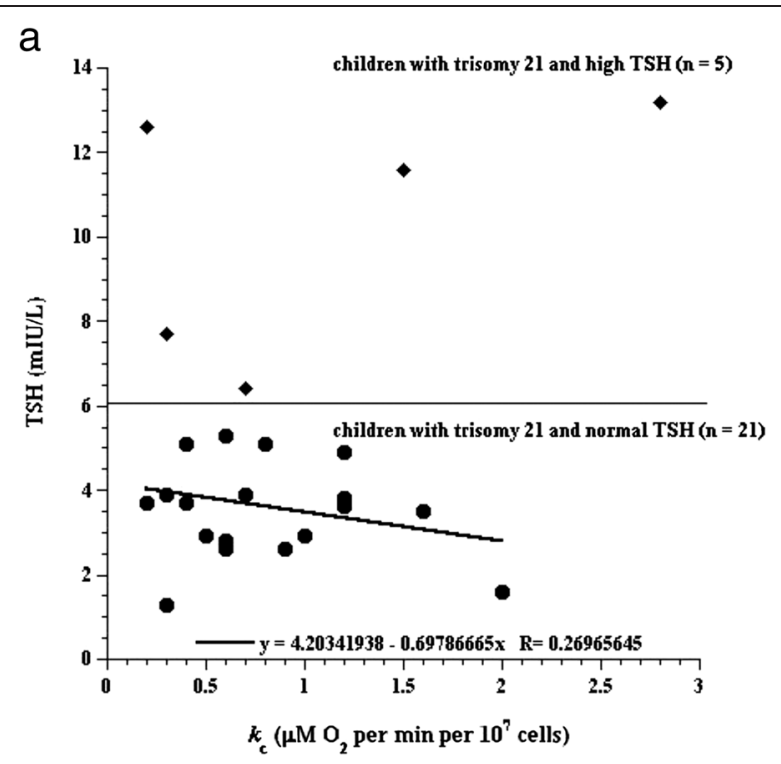

b

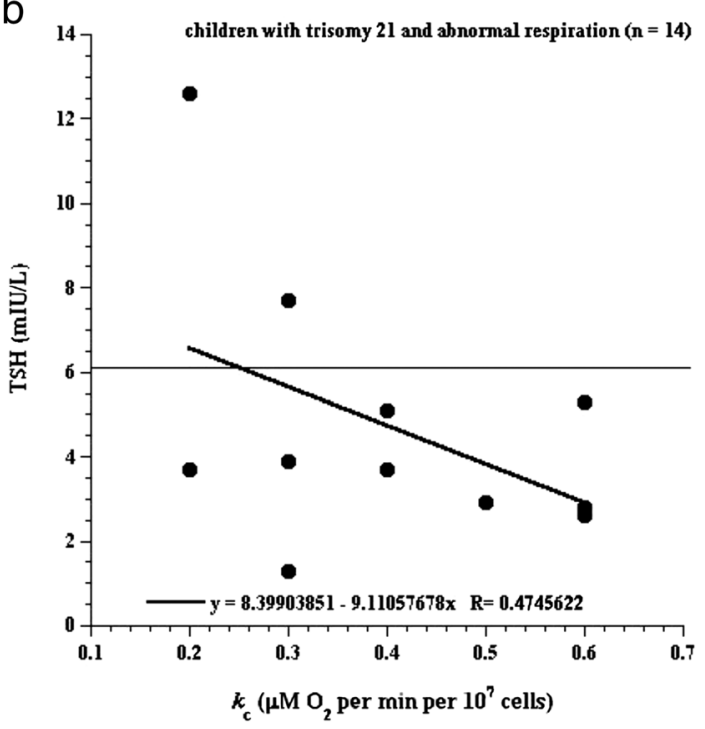

Figure 3 Lymphocyte respiration in children with trisomy 21 as a function of serum TSH. Panel a: Circles, children $(n=21)$ with trisomy 21 and normal TSH (levels $\leq 5.3 \mathrm{mU} / \mathrm{L}$; line is the best linear fit, $\left.R^{2}>0.0727\right)$; diamonds, children ( $\left.n=5\right)$ with trisomy 21 and elevated TSH (levels 7.7 to $13.2 \mathrm{mU} / \mathrm{L})$. Panel $\boldsymbol{b}$ : Children $(n=14)$ with trisomy 21 and abnormal (low) rate of respiration $\left(k_{c}<0.60 \mu \mathrm{M}\right.$ $\mathrm{O}_{2}$ per min per $10^{7}$ cells). The horizontal line reflects upper limit of normal TSH $(<6.1 \mathrm{mU} / \mathrm{L}$, please see footnote to Table 1).

min per $10^{7}$ cells (range, 0.2 to 2.8 ). Subject 8 (15-yearold adolescent male) had a TSH level of $13.2 \mathrm{mIU} / \mathrm{L}$ and a $k_{c}$ values of $2.8 \mu \mathrm{M} \mathrm{O}_{2}$ per min per $10^{7}$ cells (Table 1 and Figure 1a).

There were 8 children with trisomy 21 and congenital heart disease. Their median $k_{c}$ value was $0.6 \mu \mathrm{M} \mathrm{O}_{2}$ per min per $10^{7}$ cells (range, 0.2 to 1.6 ), and did not significantly differ from the remaining children $(p=0.238)$. 


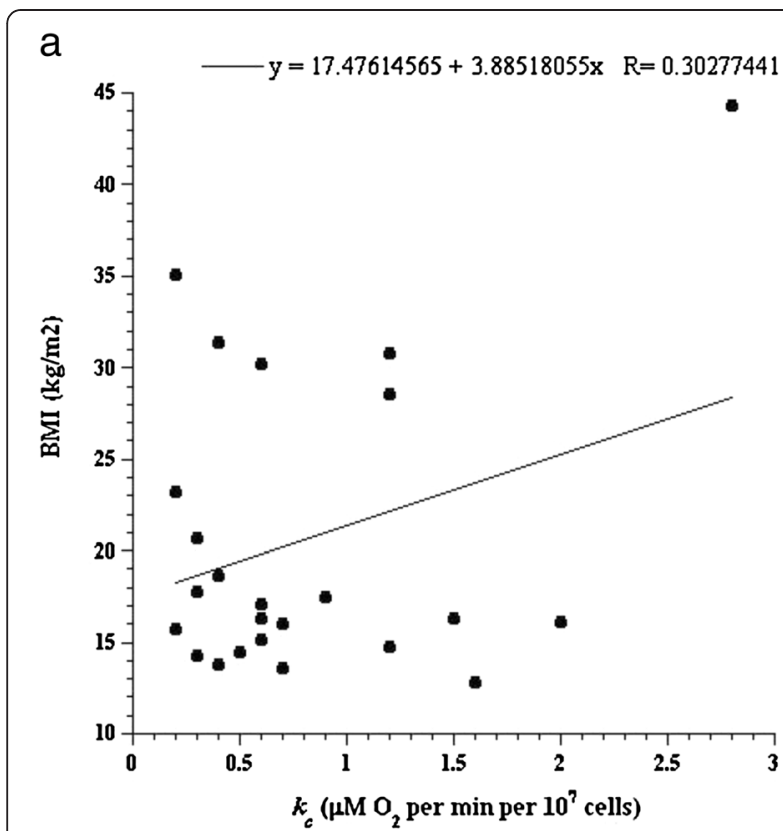

b

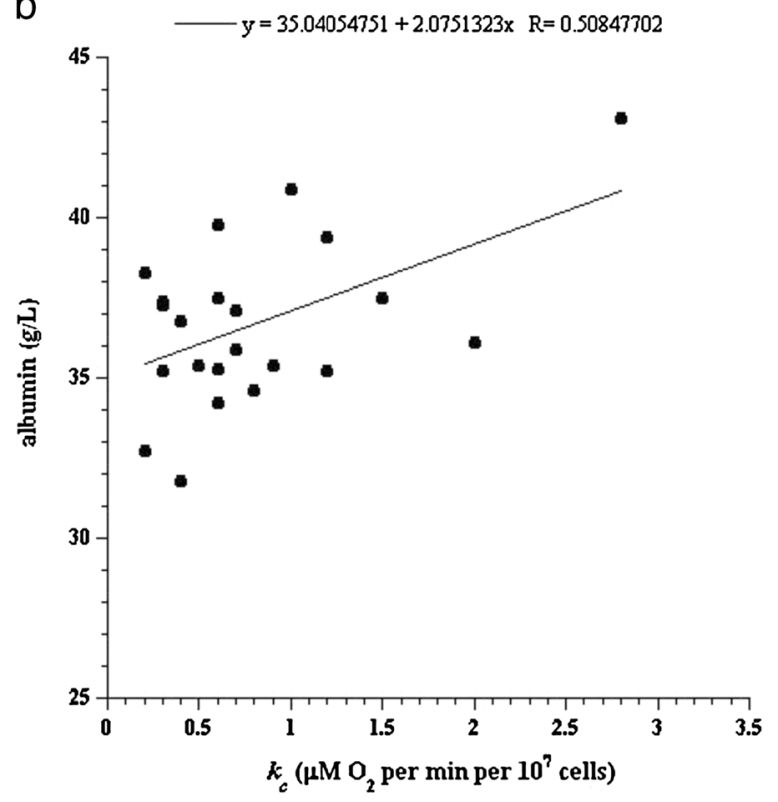

Figure 4 BMI (Panel a) and serum albumin (Panel b) as a function of rates of lymphocyte respiration $\left(k_{c}\right)$ in trisomy 21 children.
In children with trisomy 21 , the $k_{c}$ positively correlated with BMI $(R>0.302$, Figure $4 \mathrm{a})$, serum creatinine $(R>0.507)$, BUN $(R>0.535)$ and albumin $(R>0.446$, Figure $4 \mathrm{~b})$, Table 2.

\section{Discussion}

The rates of lymphocyte respiration in the children with trisomy 21 were slower than in the control group (Figure 2). These differences could reflect a relatively lower rate of mitochondrial energy conversion in trisomy 21 children that may be linked to some pathological findings pertinent to this disorder, such as defects in the inner mitochondrial membrane $[5,8]$.

The mechanism for slower rates of lymphocyte respiration in children with trisomy 21 could be multifactorial. For example, the thyroid hormone is a well known regulator of the rate of metabolism; and hypothyroidism is common in children with trisomy 21 . As shown in Figure 3b, high TSH (low or ineffective thyroxin) may contribute to the slower lymphocyte respiration in some children. Thus, thyroxin replacement is expected to improve lymphocyte respiration in those with hypothyroidism.

Of note, normal TSH values for children 2 to 7 years of age are 0.10 to $5.9 \mathrm{mU} / \mathrm{L}$ ( mean $=2.2 \mathrm{mU} / \mathrm{L}$ ) and for children 9 to 16 years of age are 0.20 to $6.1 \mathrm{mU} / \mathrm{L}$ $($ mean $=2.3 \mathrm{mU} / \mathrm{L})$. Using these cutoffs, lymphocyte respiration was found to be higher in euthyroid trisomy 21 children than those with hypothyroidism.

Body-mass index, protein metabolism (BUN, total protein and albumin), and serum creatinine positively correlated with rates of lymphocyte respiration, but only in trisomy 21 children (Table 2 and Figure 4a-b). As previously reported, protein metabolism (proteolysis, oxidation and synthesis) is linked to obesity $[15,16]$, a finding that is common in children with trisomy 21.

Close correlations were documented between cerebral $\mathrm{O}_{2}$ consumptions and mental function, including depression and dementia $[17,18]$. It is unknown if our finding of slower lymphocyte respiration in trisomy 21 children is applicable to other organs. Nevertheless, our findings are consistent with the recent reports on

Table 2 Correlations $(R)$ between serum metabolic parameters and rates of lymphocyte respiration in trisomy 21 ( $n=23)$ and control $(n=25)$ children $^{*}$

\begin{tabular}{|c|c|c|c|c|c|c|c|c|c|c|c|}
\hline \multicolumn{12}{|c|}{ Rate of respiration $(k c)$} \\
\hline & Creatinine & BUN & Total protein & Albumin & $\mathrm{Ca}^{2+}$ & Glucose & Osmolality & Cholesterol & HDL & LDL & TG \\
\hline Trisomy 21 & 0.507 & 0.535 & 0.446 & 0.508 & 0.137 & 0.048 & 0.007 & 0.091 & 0.145 & 0.092 & 0.170 \\
\hline Control & 0.192 & 0.037 & -0.146 & -0.091 & -0.136 & 0.112 & -0.009 & -0.060 & -0.080 & -0.024 & -0.057 \\
\hline
\end{tabular}

\footnotetext{
* Serum was not available in 3 patients and 1 control.
} 
mitochondrial disturbances in those with trisomy 21 [19-23]. Decreased basal 3'-5'-cyclic adenosine monophosphate, increased reactive oxygen species and impaired NADH:ubiquinone reductase (complex I of the respiratory chain) were noted in fibroblasts from those with trisomy 21 [20].

\section{Limitations of the study}

No study was found in the literature that addressed lymphocyte respiration in children with trisomy 21. Additional studies are needed in a larger population.

\section{Conclusions}

Children with trisomy 21 in this study have lower lymphocyte bioenergetics, a finding that is consistent with the known mitochondrial disturbances in these children. The clinical significance implication of this finding requires further studies.

\section{Competing interests}

The authors declare that they have no competing interests.

\section{Authors' contributions}

EHA and AKS designed the study, carried out the analysis, interpreted the data and wrote the manuscript. Both authors read and approved the final manuscript.

\section{Acknowledgements}

We thank Mr. Pramdan for running the experiments. We are grateful to Emirates Foundation for their fund support.

Received: 10 May 2012 Accepted: 12 December 2012

Published: 18 December 2012

\section{References}

1. Parker SE, Mai CT, Canfield MA, Rickard R, Wang Y, Meyer RE, Anderson P, Mason CA, Collins JS, Kirby RS, Correa A: Updated national birth prevalence estimates for selected birth defects in the United States, 2004-2006 birth defects. Res A Clin Mol Teratol 2010, 88:100-1016.

2. Luke A, Roizen NJ, Sutton M, Shoeller DA: Energy expenditure in children with Down syndrome: Correcting metabolic rate for movement. J Pediatr 1994, 125:829-838

3. Doglus S: Down syndrome: Immunologic and Epidemiologic associationEnigmas remain. J Pediatr 2005, 147:724-725.

4. Murdoch JC, Ratcliffe WA, McLarty DG, Rodger JC, Ratcliffe JG: Thyroid function in adults with Down's syndrome. J Clin Endocrinol Metab 1977, 44:453-458.

5. Abu Faddan N, Sayed D, Ghaleb F: T-lymphocytes apoptosis and mitochondrial membrane potential in Down's syndrome. Fetal and Pediatric Pathology 2011, 30:45-52.

6. Baracca A, Sgarbi G, Solaini G, Lenaz G: Rhodamine 123 as a probe of mitochondrial membrane potential: evaluation of proton flux through F0 during ATP synthesis. Biochim Biophys Acta 2003, 1606:137-146.

7. Kirkinezos IG, Moraes $C T$ : Reactive oxygen species and mitochondrial diseases. Seminars in Cell \& Developmental Biology 2001, 12:449-457.

8. Sureda FX, Escubedo E, Gabriel C, Comas J, Camarasa J, Camins A: Mitochondrial membrane potential measurement in rat cerebellar neurons by flow cytometry. Cytometry 1997, 28:74-80.

9. Prince J, Jia S, Båve U, Annerén G, Oreland L: Mitochondrial enzyme deficiencies in Down's syndrome. J Neural Transm Park Dis Dement Sect 1994, 8:171-181

10. More R, Amir N, Meyer S, Kopolovic J, Yarom R: Platelet abnormalities in Down's syndrome. Clin Genet 1982, 22:128-136.
11. Al-Jasmi F, Penefsky HS, Souid A-K: The phosphorescence oxygen analyzer as a screening tool for disorders with impaired lymphocyte bioenergetics. Mol Genet Metab 2011, 104:529-536.

12. Shaban S, Marzouqi F, Al Mansouri A, Penefsky HS, Souid AK: Oxygen measurements via phosphorescence. Comput Methods Programs Biomed 2010, 100:265-268.

13. Souid AK, Tacka KA, Galvan KA, Penefsky HS: Immediate effects of anticancer drugs on mitochondrial oxygen consumption. Biochem Pharmacol 2003, 66:977-987.

14. Lo L-W, Koch CJ, Wilson DF: Calibration of oxygen-dependent quenching of the phosphorescence of Pd-meso-tetra (4-carboxyphenyl) porphine: A phosphor with general application for measuring oxygen concentration in biological systems. Anal Biochem 1996, 236:153-160.

15. Solini A, Bonora E, Bonadonna R, Castellino P, DeFronzo RA: Protein metabolism in human obesity: relationship with glucose and lipid metabolism and with visceral adipose tissue. J Clin Endocrinol Metab 1997, 82:2552-2558.

16. Jensen MD, Haymond MW: Protein metabolism in obesity: effects of body fat distribution and hyperinsulinemia on leucine turnover. Am J Clin Nutr 1991, 5:172-176

17. Lassen NA, Christensen S, Hoedt-Rasmussen K, Stewart BM: Cerebral oxygen consumption in Down's syndrome. Arch Neurol 1966, 15:595-602

18. Garfunkel JM, Baird HW, Ziegler J: The relation of oxygen consumption to cerebral function activity. J Pediatr 1954, 44:64-72.

19. Pagano $G$, Castello $G$ : Oxidative stress and mitochondrial dysfunction in Down syndrome. Adv Exp Med Bio 2012, 724:291-299.

20. Valenti D, Manente GA, Moro L, Marra E, Vacca RA: Deficit of complex I activity in human skin fibroblasts with chromosome 21 trisomy and overproduction of reactive oxygen species by mitochondria: involvement of the CAMP/PKA signaling pathway. Biochem J 2011 435:679-688

21. Infantino V, Castegna A, lacobazzi F, Spera I, Scala I, Andria G, lacobazzi V: Impairment of methyl cycle affects mitochondrial methyl availability and glutathione level in Down's syndrome. Mol Genet Metab 2011, 102:378-382.

22. Pallardó FV, Lloret A, Lebel M, d'Ischia M, Cogger VC, Le Couteur DG, Gadaleta MN, Castello G, Pagano G: Mitochondrial dysfunction in some oxidative stress-related genetic diseases: Ataxia-Telangiectasia, Down Syndrome, Fanconi Anemia and Werner Syndrome. Biogerontology 2010, 11:401-419.

23. Valenti D, Tullo A, Caratozzolo MF, Merafina RS, Scartezzini P, Marra E, Vacca RA: Impairment of F1F0-ATPase, adenine nucleotide translocator and adenylate kinase causes mitochondrial energy deficit in human skin fibroblasts with chromosome 21 trisomy. Biochem J 2010, 431:299-310.

doi:10.1186/1471-2431-12-193

Cite this article as: Aburawi and Souid: Lymphocyte respiration in children with Trisomy 21. BMC Pediatrics 2012 12:193.

\section{Submit your next manuscript to BioMed Central and take full advantage of:}

- Convenient online submission

- Thorough peer review

- No space constraints or color figure charges

- Immediate publication on acceptance

- Inclusion in PubMed, CAS, Scopus and Google Scholar

- Research which is freely available for redistribution 